\section{Lifierpool bection.}

Chairman : 1. K. Musprutt.

ricc-Cheriman : I'roi, J. C'mmpbell Brown, 1).Sc. Commiltec:

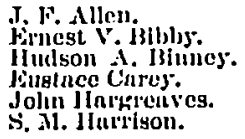

IIon. Sec. : E. G. Hullard, Quecris I'nrk, St. IIelens.

Notices of pupers and communicutions for the meetings to

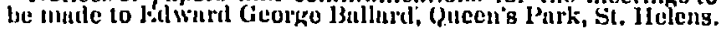

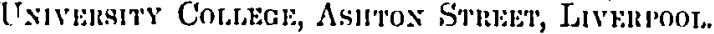 IFednestay, April ?nd, 1sS.\%.}

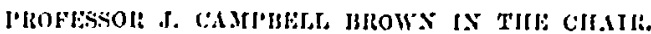

\section{ON ME'HODS OH SALPLING.}

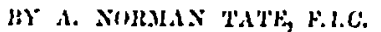

I was unable to attend the meeting of this section held last November; when a discussion took place on "Juternationnl methouls of sampling and testing Commercinl products "; but in a letter addressed to tho Chairman, with reference to the circular of Dr. Lunge, 1 ventured to express the opinion that an International nercentent to to the modes of snmpling and testing mirrlit be arrived at.

In discussing this ruestion, T consicler thint we should first, fully and fairly incuire into all the screral principles involved in sampling operations; for certainly in the operntion of assessing the value of C'mmmercial products, sampling is most important, for if the sample does not truly represent the bulk all further work is valueless. I believe that when all detnils of the characters of tho substances to be sampled, nature of packnges, changes which the sul, stance niny undergo after packing, and the conditions unler which stmulling mity take phitec, nro properly considered, sntisfactory methods of snmpling can be letimed.

1)1. Ilurter remarked, when discussing the subject at the meeting referred to, "Sampling will probably have to bo left to the intelligence of the sampler.

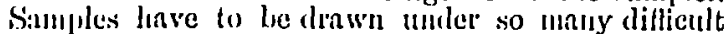
circumstances as to localities, necessibility, and packages, that a ligrid rule conlel not he drawn up, which can l,o enforced at all times, and under all conditions." No person conversant with snmpling would expect this, but it may rensomably bo hoped than celtain genoral rules, hased mon the charneter of the substance sampled, and the conditions surromeling it under different circumstnnces, may bo drawn uy and acted on by persons specinlly trained ns samplers. 'I'ho clifticulty now, so far ns I see, lics iu the fact that samples are drawn too often by persons without any knowledge or alurecintion of the eluaracters of tho sulsstnuces to bo dealt witlt.

It may be well to mention some few well-known substnnces, and tho enditions surrounding their snumpling, so as to point ont some leadiner principles which, in my opinion, shondel bo attendell to. IVhen such substances are samp. led, thero ne certnin itens leading to diserejnncies which nre of the samo goneral chumeter, as for exnmple tho mesence of moistmre, the proprortion of which is too frerjuently overlooked. Otlier itoms havo specinl roferonce to specinl sul,stances. Ono preliminary that lins to be considered is the timo and place of sampling, so tlant if a specinl strength or andity is to be delivered, tho place of clelivery and mode of sampling there, shall ho clenily understood. As a matter of practical detail, this is not always to be accomplished, and oftentimes it happens that what might liave been (quite ny to strength or guaranteed quality at point of delivery, mny fnll short at some lnter date.

With reference to the statement that samples should nlways be drawn by persons acyuainted with the jroperties of tho substrnees snmpled there comes the question "Who is best qualifical to draw snmples ?" I was surprised to find this ytuestion included in a discussion marked out a year or two ngo for the nembers of the Institute of Chemistry, viz. :- "Shonild chemists sample?" As my answer to such an inquiry I would sny that if a chemist clesire? his work to lie renlly usefil, lie shonld take every possille precnution to ensure thint the sample he tests represents what it is supposed to represent, and consequently should mako himself thoroumhly familiar with evely minute detail that has to be considered before the sample can be properly dmun. At the ineeting of the Institute of Chemistly, at which this suhject was discussed, I was astonished to find some analysts propound the view that the chemist has simply to analyse the sample riven him, and need take no note of the circumstances of its sampling. 'l'o such $\Omega$ view I strongly dissent, and would say, that it is essontinl that the chemist who makes the test should not only bo nblo to analyse and devise methods of correct sampling, but if necessary be able to sample limself. 'l'his matter of preliminnry sampling goes beyond the netunl sampling from jackages, lmving reference to the treatuent samples may underyo before and after they reach the Inborntory, until they are nctually denit with by the nnalyst. [ fear that many well dirawn samples are mucli altered in clinneter in consequenco of lanly treatment either in manner of mixing, nverariner, or crencinl trentment before the analytical process is commencel.

lieferring to detrils that aftect samples generally, I would mention as an example moisture. 'l'ho fact that the amount of moisture existing at the time of sampline ard at the time when the sample is presented for annlysis may vary, is ton frequently overlooked. Ioist sumples are not unfrequently presented to the annlyst in payer parecls, or uncler other conditions which certanly must give rise to clinnges in the percentago of moisture. Amougst sucli smmples aro sugal:s, with the exception of beet-root, the samples of which are usunlly placed in well-sealed bottles. Samples of other stugnrs come to me in paper parcels with no protection agniust loss of moisture; so also sulplinte of ammonin, nitrates of potash and soda, manures, many minerals, solid oils and fats, and in all these the proportion of moisturo is an item of commercinl neconnt. I might acld to this list considerably, but theso substances will servo to show to practicnl men the fanlt I wislı to point out.

Now as to the remedy. Tt would bo no great difitculty, for any Committec, or other appointed hody, to dofine that substances containing moisturo should bo so sampled that tho numount thicy contnin at timo of sampling, mny be correctly determined in course of annlysis. linles denling with moisture shonld refer to sampling in wet venther, transit of samples inncovered or left in $n$ clnmp ntmosphere, and the placing in bottles or otlier vessels that can bo socurely fastened and made watermoof, and other items will surgest themselves to every princtical man.

Arnin, whilst tho substances which I linvo just nlluded to lose, others may gain moisture, as fur exnmple, canstic socla, and canstic sodn ash. 'T'hesonlso should have thoir peculiarities carefully noted, null bo dealt with accorrlingly. I would alludo hero to other chnnges that may tilio place owing to tho byseroseopic properties of some substmees. Mluch alterntion miny 
occur in the outer layer of the sample as compared with the bulk, as for instance with caustic sorla ash, and blenching powder, whilst other substances which are not hygroscopic, may in wet weather become damp at points close to sides of package. In sucl cases the sampler should so sample that the sample is drawn from the entire bulk and not simply from the outer layer: One statement of a blunder made by a chemist who was called upon to sample, well serves to show what I mean. It had been arranged that a parcel of soda-nsh should be sampled and examined by lim. $\mathrm{He}$ proceeded to the works, and had the heads of two or three casks taken out; scraped ofl some of the immediately underlying ash, placed it in a bottle, took it awny with him, and sent in his report. I need scarcely say that the parties to the dispute did not settle the matter on the basis of his report when the circumstances were made known to them.

Changes in transit owing to absorption of moisturc from the atmosphere and otlier changes, cannot be eliminated from any discussion on proper sampling.

Again the physical condition of the sample must be noted. Are all the particles of the same size? If not, low far is it possible by proper riddlingr and weighing to note the relative proportions of lumps and smalls? In the case of many minerals, umless this is attended to, no proper averate of the bulk can be reached. The same holds good with smull lmmps or conrse powder, and fine powder. I lave in nyy hand a sample, contained, as you will see, in a small homceopalhic tube, which was sent me by a chemist, who professes to examine commercial samples. 'Tlis lepresents some 50 casks of callstic sodn ash of rollyh character, with many large and small luujes and much fine powder. This so-called sample is not even powdered, with the object of gretting something like nu nierage, und if it land been most likely it would not have represented the bulk, and to bring such in sample before anyone as the rejresentative sample of 50 casks of soda ash is an instance of either ignornese or gross neglect of circumstances yertaining to proper sampling. An amusing instance of what $I$ consider must have been fanlty 'sampling, took place in the well known birkenhend coffec-chicory case, when sereral members of the 'lown Cumcil met togrether and weighed out and mixed quantities of chicory and cofice, and after mixing in their way, sent samples to diflerent analysts, nud cluchled over the reports received as showing how widely analysts dificr. It is a matter exceedingly difficult, unless specinl precantions are taken, to ensure a thorough avernge suixture of ground coffee and chicory. And allhough it may' lave given these inexperienced Birkenliead tuwh councillors some pleasure in chuckling over the results, the reason of the differences would be clearly unough apparent to those thoroughly experienced in the sampling and mixing of such substances,

There are other points connected with snmplinge based upon the mode of division. lor exmmple, it is not unfrequently the caso that one or two pieces of barks selected at randoun ate handed il as samples of many packinges to le tested for guinine or otlier alkaloids. Such a morle of sampling is grossly faulty. Secls will often afiord better opportunity for taking samples from diflerent. parts of bulk so as to get a fair averagc, but owing to diflerent sizes of seeds, and many ot lee clunracteristics, really good sumples aro rurely obtrined umless specin! precautions are olsserved. $\Lambda$ cuse was before no not fong since, when many particles of sund, gravel, and clirt of various kinds, were mixed with bones (the bones of course boing the valuable substance), but not the slightest care was tricenble in tho selection of tho somple, for after it had leen drawn from lulk and divided into separate parcols, one pareel combinised honcs fairly frec from gravel, sand, etc., and another: contrining almost the whole of such matters that hal been drawn from the packages. 'The chemist's aid was invoked to deternine thie amount of siliceous matter in the dilferent samples, and any person conversant with the dotails of sitch exanimation will readily see how widely the results must linve differcel. I might add many other examples of faulty sampling as conducted by commereial brokers and
merchants ; in fact the process of sampling as conducted usually in merenntile offices reynires very careful investigation and revision.

'I'lere is nuother cause of error in sampling, and that is the tendency of the bulk to sepuate into layers, when solid matters in suspension in linuids stibside, and are not fully mixed up before a sample is taken from bulk. No doubt many exmmules of such kind will sugrest themselves to practical men. I have found this often in the case of liquid cxtracts used for tamming purposes. 'J'hese without ex jerience might be suprosed to be of the sime character thiongliout the contents of a cask, without any tendency to sejarate into layers, but, oftentimes there is a thick dense layer at the lower purt of the cask, and a more Huid layer at the tol. 'lihis has, 1 know, given rise to many discrepancies in the tests rejorted, resprecting the so-called same simples liy ilitirent ehemists. These same extrats, if carefully watched lluing different methods of sampling, will atlord gool examples of clatuges in percentuge of the more valuable constituent. Another exumple of layers is slown with palm oil. When packed in Alrica it is sulticiently liypuid to allow of solial impurities and water settling out before the oil becomes ynite solid. It therefore follows that every special preciution should be tatken to note under what circumstances, and in what parts of the cask dirt and water may be found, as it is ustual, and of course desirable, for a deduction from the total weight of the contents of the cask to be male, so that only oil is chariged for.

C'ertuin circumstances commected with a process of manufacture may often lend to strumge results in sampling, and fretuently through carclessitess. For instance inrefining oil, the vil mny be placed in the tank, from which it is praclied, before the liepuid or chemical with which it has been washed or treated has sul sided. In sucli eases, whilst the greater number of the enslis packed may contain a thormolng good merchnutuble jroduct, one or two ensks may liave a large ndmixt une of water and otlser impurities.

Such facts as these, and others met with by practicnl samplers, sugrost the question, "l'youn how muny pacliages shoulel a sample be drawn?" "llant is, from the whole number, or if not, from whine proportion of the whole number. In muny conses it is desirable tlint the contents of eyery singlo packane should be alike, ill other casses lhis is almost jumpricticalule, nnd is not absolutely essential, provided tho varintion isuct grent. On this point much may be snid, and al] interested in correct sampling will alo woll to gire the matter most careful consideration. Circumstances surrounding tho sampling of commercinl products often prevent Ile sample from being drawn from the whole of the prackinges, and, therefore, unless there is frent uni. formity in the strength: and chameter of the contents of ench, a really good avernere is not attnimable. At the snue time it may he fairly said, that no one pnckage of any panticular lot of goouls, should vary willely from otlices. l'ersons necestomed to sampling on loond shijes, on flats, in railway trucks, in wrehouses, and other julaces, will, I think, fully alpureciuto the dillienltios 1 have, just ulluded to.

'There are many' ot her points I might mention with cximples, concorning tho sampling of very many other rnw suaterials and manufactured juroducts that ! have 
not alluded to. What I linve said will perhnus serve to show the many diflicultics that lie in the way of bringing about international or other agreements $\mathrm{as}$ to nodes of sampling. Still, I think the atteny,t desibalile, and believe the result attainable. Jint the untter must be denlt with only by tlioso who are thoroughly familiar with all the details that have to be consiclered. $\Lambda$ committec may be ajpointed, as lias been surgrested, of nembers of the Institute of Chemistry, Society of Chemical Industry, and Society of l'ullic $\Lambda$ ualysts, to take preliminary steps and settle the basis of general work. Such committec could probably cleal with such a question is the morke of takingre and treating samples that contain moisture, and sipply some course of jrocedure that would prevent many other disadvantages which now acerue from a disiegnard of necessnry precautions, but a general committee would, I consider, l,o quite unable to deal with many matters of detail. Only such persouss as are thoroughly faumiliar with every single rletail pertaining to special articles can fully and fairly discltss methods of rlealing with then. J'he general committec conld make imruiry, and select jersons having the confidence of certain trades, to deal with matters and products used nud made by them, and these persons, whether members of the general committec or not, could rejort the results of their delilerations, which condd then be forwareled to all persoms interested, and, if necessnry, meetimes of representatives of such trades could be colled to lisenss the ynestion more fully. 'l'here alreacly exist diflerent triales associations which could be imvited to discuss these matters, and bring to benr upon them special knowleclue in matters of sampling. Special knowledge of all minute details is alsolutely essont inl, and the introduction of theoretical considerations only, witliout the test of practice, nuy becoune a solurce of error:

Fou wi]] sec from what [ lanve said that my sulogestion is a gencrul committe comprosed of members of diflerent sncieties interested in the taking of correct samples. Such a committee to deal with general prineiphes, to watch for instunces of incorrect procechure, and take steps to appoint proper persons to consider ench special sul,ject, arrange for the circulntion of experts' reprort to the trades and persons interesterl, and adopt methods to get decisions arrived at, and male practically servicenble as rules for guidance under tho special circumstrnces of ench case. lave already alluded to what I consider an important element commected with sampling, viz., that chemists should grive more attention than many do to methorls of sampling, and study in every possible wny the screral chalacteristies of the sulistances they have to eximine, so ns to be able not only to indicato how samples slould he dinwi, but, if necessary, be enjable of superintending tho operation of performing it themselves. I think this cannot be miged too strongly. 'l'ten ngain it is, I think, desirable that more care slould liu tnken in training men for the special work of saunling. Illere are alrendy many men engiged in alifierent senports and munufacturing sentres who Jave land Jengrhened nnd viried experience as samplers, nud who kinow tho helinviour of tho smb. stances they denl with moler nlmost every conceivable

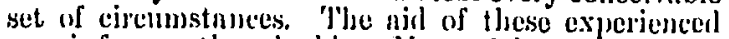
men is frepuently valunlite. Mnny of the men engraged in the Jomilon docks and wharves are fine exampiles of what can be done by training in sompling, and have often noten with plensuro tho knowlenlge of detnil mad care in manipulation which they bring to henr on the samp pling of diflorent substances. I must not omit, iil conclusion, to mention eare on tho part of tho ehemist in the putting uside, under proper circumstances and comditions, of smunjes thes ho Jas cxamined, so that they may undergo no change, and be obtainable for reference should disputes arise.

\section{J)ISCUSSLON.}

Mr. J. Chnfy opened the discussion on the mper. He did not think it was possible to exngrgerate the importance of the subject which Mr. Thate had brought belore them that evening so elnborately and so well. He yuite agreed with all $3 \Gamma_{r}$. Thate had snid nbout the importance and also the difticulty of proper sampling. He thought that the sampling of goods in his own trade was had enough, but Mir. 'Tate had described cases where goods in casks settled into layers, and tho unfortunate sampler liad to roll the casks about for a spell before he could get snmples at all. It seemed to be a labour of hopeless mingnitude to sample fairly in such cases. Nerchants and traders paid rery littlo attention to accurate sampling, and without accurate snmpling reliable aualysis was injossible. In a case lie remembered some years ngo, where a large quantity of copleer ly'rites repuired to be sampled, the percentare of copuer varying from 2 to 3 per cent. up to 10 or 12 per cent., buyer and seller each agreed to pick out a lump in turn, nnd of course as each picked out lumps likely to stuit his interests the results were widely different from the truth. Of course that would not lie done in a jlace where they renlly understood colper ore sampling. 'The jroper sampling of Jarge cargoes was no doubt an expensive nflair, but sampling conkl only be done in a thorougll wny when a large proportion of a cargo was drawn upon for sampling. He wished Mr. Tale had answered the question how many casks in a given lot of goods should bo sampled-that was, what proportion. He regneled that as a very important matter. His iden was that a very much larger propertion should be sampled than was now the rule. Less than one in three he should consider a mistake; and he thought it wonld be well if analysts stnted on thejp certificates what p'oprortion of a given quantity of gools the samples were clrawn from. It often liapiened that the scller asked the sampler to como and sample the goods at a time when he conld only fet at a small proportion, and if the annly'st stated in his certificate how many samples he lind received, or what proportion of the whole they had been dirnwn from, it would be a very desiruble thing. $A$ certificate at pyesent might be yuite right as far as it went, but it miglst not represent the whole; and if so stnted no clisnpuointment conld be experieneed, und sellers would take care that the samplers camo when they could have proper aceess to all the goods requiring to be sampled. Sceing the enormous number of trales interested he was afruid that the proposed representative committee, if formed, woukd be rather unwieldy. It would bebetter if all the members or representatives of a few of the larer trades were to meet and formulnte their views, mol thes submit them to some central committee. Ilo rejeated thut it was impossible to exngerernte the importance of this ruestion of fair sampling.

1)r. Hun'ter snid that Mr. Thite lond given them a very exhaustive account of the ditficnlties which beset sampling; and the result of hearing the paper lad been to strengthen lis view that it was impossiblo to givo general directions as to low samples wero to loo tnlien; and the difliculty of nriving $n t a$ concise set of lules for drawing samples was very grent indeed.

Mr. Aluke said po was afraid that $n$ goneral com. mittee to discuss sampling in various trades would prove a council of words without knowledge. Ho would not caro to bo on a committeo which would discuss allenli sampling, for instanco; nor did ho sujuluse that a jonlu oil morchunt would bo much at home with copjer ores. Ho did not sec how it was possiblo to lny down witten rules and instructions 
for sampling in all trades. $\Lambda$ twenty-five years' cxperience of samplingr a substance in which nccuracy of sampling was of the very first importance convinced him that there wero three reyuisites for the sampler-integrity, cxperience, and biains. Whatever class of goods had to be sampled, men of interrity must be had in the first instance. Iruch mischicf was caused in times past tlirongl roguery in sampling, and therefore an honest, ly might man was the first essential. 'The next refunisite was experience. To send a young clicmist witliout experience of the particular article was a mistake. A man with practical experience was to be preferred to one with scientific training without the experience. 'J'hen, finally, they must lave men with right-down common sellse. Given these requisites of integrity, experience, and brains they conld take samples.

Mr. 11. T.IT, jun., snid it might be interesting to know that in the beetroot sugar tiade they always sold on annlysis. An associntion liad been formed and a public sampler was appointed in Jondon, in liverpool, and in Circenock, by whom three samples of encli lot of beetroot sugar were taken. One went to the sugar refiner, the oflier to the analytical clicmist appointed by the association, and the third for reference. 'Thus all the samples passed througl onc man's liands, aud he lind a statl of samplers upon whom he could depend. Low sufris were not sulyposed to be sold by analysis. The nssociation had only been formed two or three years, and it was found to work well. The samples they now got conld be depended upon.

The Chaldess said that where in the opinion of the analyst the sample was not a proper one, lie ouglit to let that fact aplear on the face of the certificate in some form or other. It would be easy to say that he had received such and snch a sauple, and that in his opinion it was not a good sample, or not in proper condition. For instance, if an article likely to give off moisture was clelivered to him in brown paper instead of in a bottle, that fact ought to bo stated, and its probable effect on the sample. He thought Mr. Allen had scarcely followed the argument as to witten instructions. It was true that no written instructions could supply integrity, nor jet brains, but they would be nseful, he thought, in imparting to others the experience of those who liad gone before. Ho thought Mr. Circy had suggested the proper course to pursuc-that was for a few skilled persons in the leadine branches of manufacture to meet and draw ul what they considered to be proper instructions botl $f_{\text {for }}$ snupling and testing, and sulmit those in structions to a central committee composed of one or other or all the three societies which had been named. He was sure they were all obliged and imlebted to Mr. 'late for his paper.

\section{HE.T.T.}

Mr. T.t't: As to the number of casks or parcelis to be sampled in a cargo, cnses had occurred to linim where ho had becin able to draw samples from every single eisk; and then there hind been no disjuttes, the resinlts of independent unnlyses heind pretienlly the same, and experience indicated pretty clenrly that that wins the best course of jrocedure. Ile saw no reason why the number of casks sampled should not be stated on the certiticate, and ho thourht the if done, it wonld learl to some alteration in tlie modo in which parcels were sampled. Je did not intend to suggest that the coumitteo he had spoken of should lay down rules for cuidance in every glecial case, but thint such a committee sliould wnteli and press on improvoluents pertaining to sampling, nusl should lave tho power to nomimate prersous specially nepuatinted with certnin trades and articles, to deal with any diflicultios arising in connection therewith, and draw up a set of rules for discussion and nuproval by the more general committec having charge of the whole question. M/r. Allen, he thought, lind rather misunderstood him as to the employment of chemists as samplers. He arreed that it would be very wrong indeed to send a youms chemist, an apprentice, perhaps, to samplo a substance which he had nerer seen. Nothing could have been further from his mind ; but chenists competent to amalyse an article ought to bo able to indicate liow the samples shonkl be drawn, and if necessary be able to draw them themselves. He was glad to hear what Mi. Jenry 'Tate liad said about the sampling of licet sugn:; for that whs the sort of thing he had had in his own mind. Here one trade dealingr in one specinl substance harl taken action to avoid disputes as to sampling; and by a very simple process apleared to have sueceeded. 'l'he same or a similar sj'stem was what they wanted aplylying to a much grenter extent. It was a juactice whicli ho almost invaivably adopted himself, in analysing low sugars, to report the condition in which the samples reached him, and the probable loss of moisture, etc.; and that was what he thonght analysts ought to do not only with sugar but with other substances.

\section{UISCUSSION OA DR. WAMJUUGER'S RAPEA}

$$
1 /(1) ; 1 /, 1884 .
$$

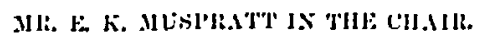

Mr. J. liswwek A ILtax: 1)r. Hamburerer deserves our thanks for his interesting and valuable pineer. The subject he lins introduced contimues to be me of practical importance to the manufacturer, nol is one on which we fear there is still a wirlespread ignorance and prejudice. Damage to regetation is of ten attribited to chemical vajour's, which is solcly dono by natural causes. Since our last meeting, a crentleman lins been witing to the J/lanehester Ginardian connplaining thant Jumlan l'ark is being destroyed by the chemical fumes from Widnes aud liumeoru. It secmed to me so extraordinary that noxious gastes should prove so destructive at a distance of 1 is miles, that I went over to iuvestigate the matter, and I found no proof whatever of the least clamage lucing done by the chemieal fumes from the Whilnes ilistrict. Nany trees are dying, but from manifest natural causes, the most dominant of which are:-

1. l'oor, slinllow, sundy soil.

2. J)rimngc.

3. Hileak asject.

4. Exposure by removal of shultering trees.

i. Hlard winter's.

(i. Are, natural decay.

Some years ngo it fnimel complained of his hedres heiner severely injured by tho sntoko from St. Ilelens. 'l'here lind been a storm from tho west, and the hedges on the side exposed to tho wind were ruite liown; but it liaprened that there were four hayricks stumling at several yards interval from encls other. l'ortions of the liedge opposito theso riclis were screoned by them from tho west wind, but were not serecned from st. Helens, which lay considerably more to the north of west. Wherever the hedgo wiss screcned it was green, whilst tho portions opllosite tho rajk between tho ricks were brown, just as was the remnimer of the exposed portion of the liedge. During the last fow day's I linyo collected theso specimens (specimens exhilited) of blighted thorms and injured rose trees. Jooking nt the trees 1 should hitve said they lind been injured by chemical rapours, 